\title{
Bentuk kegiatan ekstrakurikuler PMR di SMPN 8 Malang untuk menumbuhkan kepedulian sosial siswa
}

\author{
Martaningsih, I Dewa Putu Eskasasnanda*, Agus Purnomo \\ Universitas Negeri Malang, Jl. Semarang No. 5 Malang, Jawa Timur, Indonesia \\ *Penulis korespondensi, Surel: dewa.putu.eskasasnanda.fis@um.ac.id
}

Paper received: 05-01-2021; revised: 15-01-2021; accepted: 30-01-2021

\begin{abstract}
Purpose this research is describing the activity of Red Cross Youth Volunteer in Public Junior High School 8 Malang to grow social concern. This research uses a qualitative approach with descriptive type research. Purposive technique is used to gather the informant's data. The procedure of data aggregation comprises of observation, interview, and documentation. This research found the activity of Red Cross Youth Volunteer are regular exercise, health alert, socialization to another extracurricular and social service. The activity purpose to increase student's social concern.
\end{abstract}

Keywords: red cross youth volunteer; social concern

\begin{abstract}
Abstrak
Tujuan penelitian ini adalah mendeskripsikan bentuk kegiatan ekstrakurikuler PMR di SMPN 8 Malang untuk menumbuhkan kepedulian sosial siswa. Metode penelitian ini menggunakan pendekatan kualitatif dengan jenis penelitian deskriptif. Pengumpulan informan yang digunakan yaitu teknik purposive. Prosedur pengumpulan data meliputi observasi, wawancara dan dokumentasi. Hasil penelitian ini adalah bentuk kegiatan ekstrakurikuler PMR SMPN 8 Malang diantaranya, yaitu latihan rutin, siaga kesehatan, sosialisasi ke ekstrakurikuler lain, dan bakti sosial. Kegiatan tersebut bertujuan untuk meningkatkan kepedulian sosial pada diri siswa.
\end{abstract}

Kata kunci: ekstrakurikuler PMR; kepedulian sosial

\section{Pendahuluan}

Dewasa ini banyak ditemui remaja yang tidak mempunyai kepedulian sosial dan hanya mementingkan dirinya sendiri tanpa memperhatikan sekitarnya yang membutuhkan bantuan (Prahesty \& Suwanda, 2016). Berdasarkan hal tersebut, dikhawatirkan generasi muda Indonesia mengalami penurunan degradasi moral. Untuk mengatasi hal tersebut, penguatan pendidikan karakter terutama karakter kepedulian sosial harus ditekankan agar generasi muda tidak bersikap acuh tak acuh dan lebih peduli terhadap keadaan sekitarnya. Kepedulian sosial merupakan sikap yang harus terus ditumbuhkan guna membentuk tatanan hidup bermasyarakat dan berbangsa yang bermartabat, karena remaja merupakan generasi penerus bangsa yang menjadi panutan masyarakat luas, di tengah arus perkembangan zaman yang sudah modern ini (Isro'diyah \& Warsono, 2017). Kepedulian sosial diwujudkan dengan tindakan memberi bantuan kepada orang lain dan masyarakat yang membutuhkan (Fathurrohman et al., 2013). Sikap membantu meringankan beban orang lain ini diharapkan dapat menjadi suatu kebiasaan, sehingga terbentuklah karakter kepedulian sosial pada generasi muda Indonesia.

Sekolah adalah satuan pendidikan jalur formal yang bertujuan untuk mendidik siswa agar berkompeten dan mampu menghadapi tantangan masa depan. Pendidikan mencakup berbagai aspek yang dapat meningkatkan kompetensi generasi muda dalam menghadapi 
berbagai tantangan masa depan (Prasetyo, 2010). Untuk mewujudkan hal tersebut, diperlukan pengembangan karakter pada diri siswa. Salah satu strategi pengembangan karakter siswa di sekolah dapat dilakukan melalui kegiatan ekstrakurikuler (Yusuf et al., 2012). Kegiatan ekstrakurikuler berfungsi untuk mengembangkan kemampuan dan rasa tanggung jawab sosial, serta potensi dan prestasi peserta didik (Makhfudzo, 2014).

Kegiatan ekstrakurikuler dapat meningkatkan aspek kecerdasan sosial dan kecerdasan emosional. Berkaitan dengan aspek kecerdasan sosial, kegiatan ekstrakurikuler dapat meningkatkan rasa kepedulian sosial pada diri siswa, yang nantinya akan memberikan kontribusi penting dalam memupuk kesadaran nasional (Makhfudzo, 2014). Berdasarkan pernyataan tersebut, kegiatan ekstrakurikuler dapat menjadi sarana untuk menumbuhkan karakter kepedulian sosial pada diri siswa. Ekstrakurikuler Palang Merah Remaja (PMR) merupakan salah satu ekstrakurikuler yang berperan untuk menumbuhkan kepedulian sosial siswa terhadap orang lain. Hal ini dikarenakan dalam ekstrakurikuler PMR berpijak pada nilainilai kemanusiaan yang senantiasa harus diterapkan oleh para anggota PMR terhadap sesama.

Ekstrakurikuler PMR merupakan salah satu wadah pembinaan dan pengembangan anggota remaja dengan tujuan membangun dan mengembangkan karakter anggota Palang Merah Remaja yang berpedoman pada Tribakti PMR dan 7 Prinsip Kepalangmerahan. Siswa PMR dilatih agar memiliki kepedulian terhadap teman atau orang lain yang membutuhkan pertolongan (Isro'diyah \& Warsono, 2017). Ekstrakurikuler PMR membentuk siswa PMR agar dapat mempraktikkan ilmu yang telah dimilikinya kepada teman dan orang lain yang membutuhkan bantuan. Contohnya; memberi bantuan kepada teman yang terluka setelah bermain olah raga, mengarahkan teman untuk meminum obat ketika tiba-tiba sakit di sekolah, dan melakukan bakti sosial, dan lain sebagainya.

Bentuk kegiatan ekstrakurikuler PMR di SMPN 8 Malang berpedoman pada nilai-nilai yang terkandung dalam Tri Bakti PMR dan 7 Prinsip Palang Merah dan Bulan Sabit Merah. Kegiatan ekstrakurikuler PMR SMP Negeri 8 Malang diantaranya; latihan rutin, siaga kesehatan, bakti sosial, dan sosialisasi kepada ekstrakurikuler lain. Hal ini dilakukan sebagai upaya sekolah agar siswa PMR SMPN 8 Malang dapat mempraktikkan ilmu kepalangmerahan yang dimilikinya kepada teman dan warga sekolah. Hal ini menjadi fokus penelitian yang akan dikaji oleh peneliti, yaitu mengkaji tindakan kepedulian sosial yang dilakukan oleh siswa PMR berupa pertolongan atau bantuan kepada warga sekolah yang membutuhkan berkaitan dengan ilmu kepalangmerahan yang telah dipelajari di SMPN 8 Malang.

Penelitian ini berjudul "Bentuk Kegiatan Ekstrakurikuler PMR SMPN 8 Malang untuk Menumbuhkan Kepedulian Sosial Siswa". Peneliti ingin mengkaji lebih dalam tentang kaitan kegiatan ekstrakurikuler yang ada di ekstrakurikuler PMR SMPN 8 Malang untuk menumbuhkan kepedulian sosial pada diri siswa.

\section{Metode}

Penelitian ini menggunakan pendekatan kualitatif dengan jenis penelitian deskriptif. Sumber data yang digunakan adalah sumber data primer dan sumber data sekunder. Lokasi Penelitian di SMPN 8 Malang. Teknik pengumpulan informan yang digunakan yaitu teknik purposive. Prosedur pengumpulan data meliputi observasi, wawancara dan dokumentasi. Analisis data menggunakan model Miles dan Huberman yang memiliki empat komponen yang diawali dengan pengumpulan data di lapangan, kemudian peneliti mereduksi data sesuai fokus penelitian, selanjutnya peneliti menyajikan data dan yang terakhir penarikan kesimpulan. 
Tahap penelitian ini terdiri dari tahap pra-lapangan, pekerjaan lapangan, analisis data, dan tahap penulisan laporan.

\section{Hasil dan Pembahasan}

\subsection{Hasil}

Kegiatan ekstrakurikuler PMR di SMPN 8 Malang dilaksanakan sesuai dengan program kerja. Untuk memahami mengenai kegiatan yang dilakukan dalam ekstrakurikuler PMR di SMPN 8 Malang ini diteliti empat kegiatan yang menjadi pokok dan merupakan kegiatan yang berkaitan untuk meningkatkan kepedulian sosial siswa, diantaranya adalah latihan rutin ekstrakurikuler PMR, siaga kesehatan saat upacara, bakti sosial ke panti asuhan, dan sosialisasi ke ekstrakurikuler lain.

\subsubsection{Latihan Rutin Ekstrakurikuler PMR}

Latihan rutin ekstrakurikuler PMR adalah kegiatan yang bertujuan untuk memberikan pembelajaran tentang kepalangmerahan kepada siswa PMR. Latihan ini dilaksanakan rutin setiap satu minggu sekali pada hari Jumat. Melalui penelitian diketahui materi yang diajarkan pada saat latihan rutin diantaranya adalah (1) pertolongan pertama, (2) sanitasi kesehatan, (3) kesehatan remaja, (4) sejarah kepalangmerahan, (5) kepemimpinan, (6) kebencanaan, dan lain-lain. Materi yang diajarkan dalam PMR memuat tentang ilmu kepalangmerahan dan ilmu kesehatan yang bersifat teori maupun praktik.

Melalui latihan rutin, diharapkan siswa PMR dapat mengamalkan ilmu yang didapatnya kepada temannya di lingkungan sekolah, keluarga, dan masyarakat. Untuk lebih jelas mengenai bentuk latihan rutin bisa dilihat pada Gambar 1 berikut.

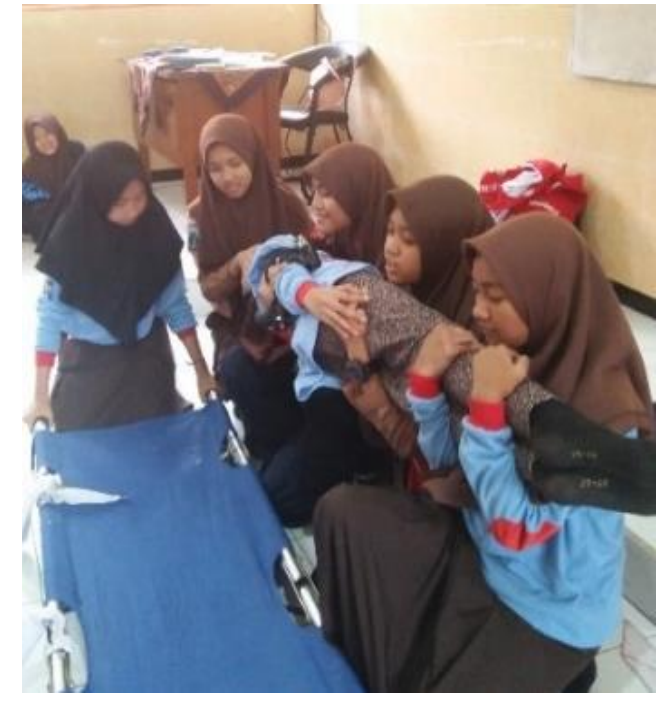

(a)

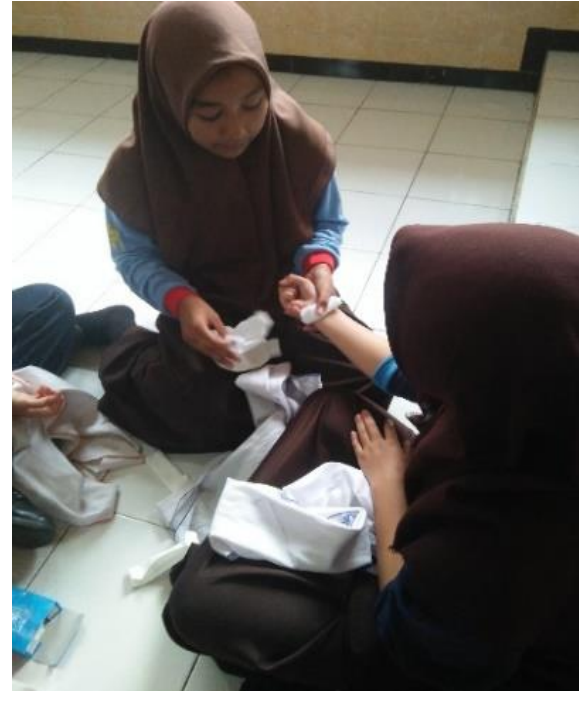

(b)

Gambar 1. Siswa PMR Melakukan Praktik Pertolongan Pertama pada Saat Latihan Rutin Sumber: Dokumentasi Pribadi (2019)

Gambar 1 terlihat bahwa siswa PMR sedang melaksanakan kegiatan latihan rutin yaitu praktik pertolongan pertama. Isi dari materi pertolongan pertama ini adalah mempraktikkan cara menangani korban kecelakaan yang mengalami kasus trauma (terdapat luka) maupun 
kasus medis (tidak terdapat luka). Tujuan dari pemberian materi pertolongan pertama ini yaitu agar siswa PMR sewaktu-waktu dapat memberikan pertolongan pertama kepada orang yang membutuhkan bantuan. Materi pertolongan pertama ini meliputi pembidaian (penanganan patah tulang), pembalutan luka, penanganan luka, dan pemberian obat-obatan.

Sanitasi kesehatan juga merupakan materi yang diajarkan ketika latihan rutin. Dalam materi sanitasi kesehatan diajarkan pola hidup bersih dan sehat. Sebagai seorang PMR, siswa diharuskan memiliki pola hidup bersih dan sehat serta mampu mengajak teman, keluarga, dan orang lain untuk menerapkannya. Penerapan pola hidup bersih ini sangat bervariasi, salah satunya adalah cuci tangan bersih sebelum melakukan aktivitas apapun. Segala aktivitas manusia tidak terlepas dari kuman penyakit, maka dari itu seseorang harus mengetahui cara cuci tangan yang benar agar selalu bersih dan sehat. Pada Gambar 2 siswa PMR belajar bersama mempraktikkan cara cuci tangan yang benar.

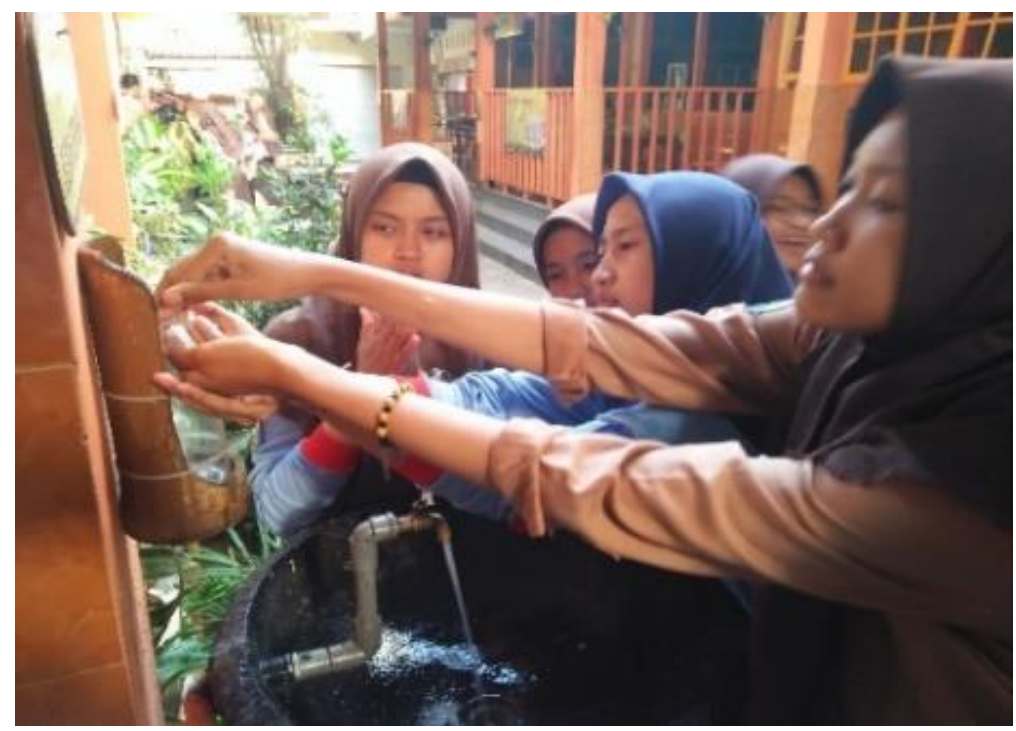

\section{Gambar 2. Siswa PMR Praktik Cuci Tangan Bersama-Sama Ketika Latihan Rutin Sumber: Dokumentasi Pribadi (2019)}

Materi latihan rutin adalah materi kesehatan remaja. Pada materi kesehatan remaja ini siswa diajarkan tentang cara menjaga kesehatan diri. Harapannya, selain dapat mempraktikkannya pada diri sendiri, siswa PMR juga dapat mengajarkan kepada teman, keluarga, dan orang lain. Adapun materi kesehatan remaja yang diajarkan dalam ekstrakurikuler PMR meliputi; (1) pengembangan potensi diri, (2) pencegahan HIV/AIDS, (3) bahaya rokok dan NAPZA, dan (4) pendidikan remaja sebaya. Materi kesehatan remaja diajarkan oleh pembina ekstrakurikuler PMR melalui pertemuan di kelas, dimana siswa wajib mencatat materi tersebut (Gambar 3). 


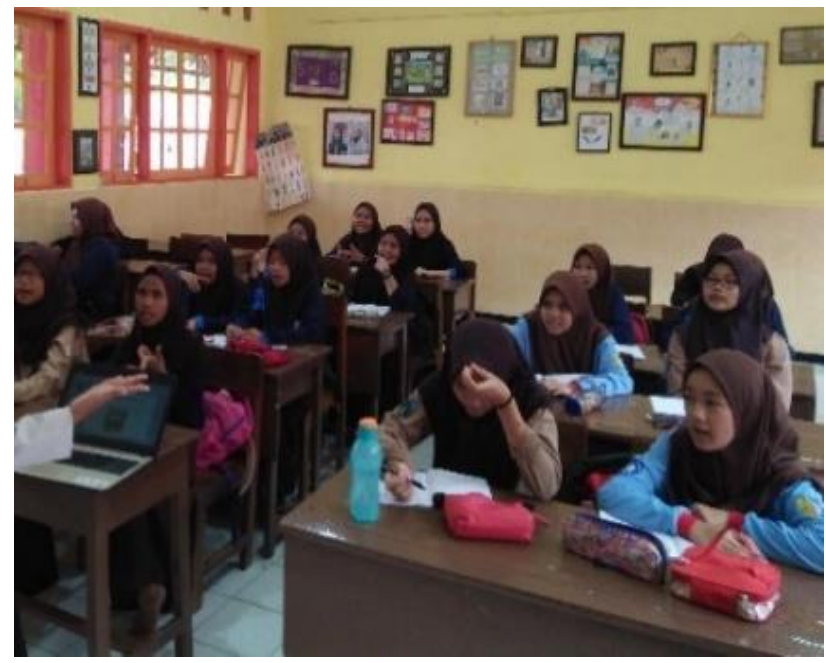

Gambar 3. Siswa PMR Mendapatkan Materi Kesehatan Remaja di Kelas Sumber: Dokumentasi Pribadi (2019)

\subsubsection{Siaga Kesehatan}

Siaga kesehatan adalah salah satu program kerja PMR yang bertujuan untuk membantu pihak sekolah menjaga kesehatan siswa selama siswa belajar di sekolah. Pada hari Senin dan hari-hari besar nasional anggota PMR bertugas mengawasi siswa yang sedang melaksanakan upacara bendera. Apabila sewaktu-waktu terdapat siswa yang mengalami sakit, siswa PMR berkewajiban memberikan pertolongan pertama berdasarkan ilmu yang diajarkan pada saat latihan rutin.

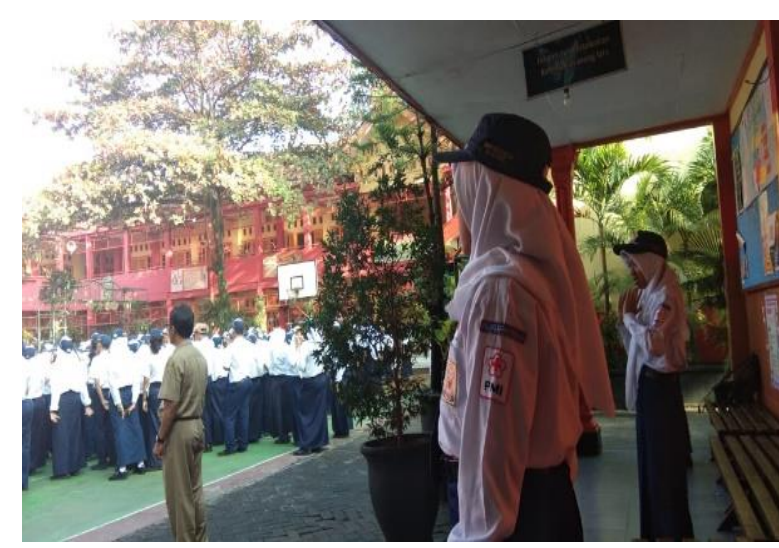

(a)

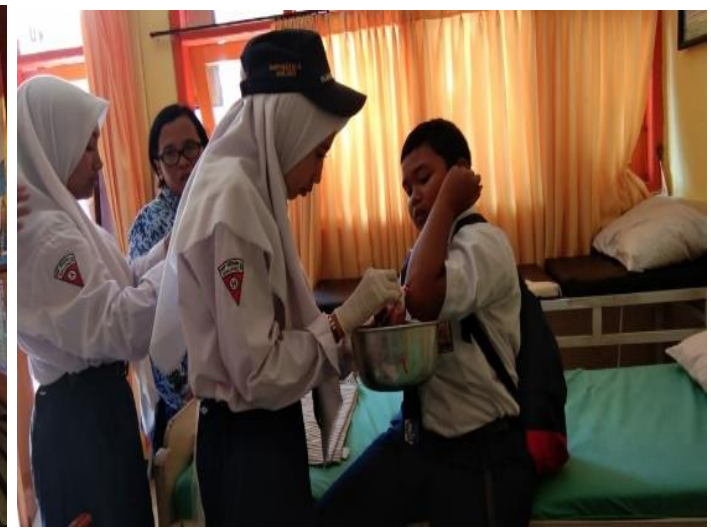

(b)

Gambar 4. (a) Siswa PMR siaga kesehatan di lapangan saat upacara bendera, (b) melakukan pertolongan kepada temannya di ruang UKS

Sumber: Dokumentasi Pribadi (2019)

Berdasarkan Gambar 4 tersebut, tampak siswa PMR berperan aktif di lingkungan SMPN 8 Malang, diantaranya adalah melaksanakan siaga kesehatan pada saat upacara dan membantu teman yang membutuhkan pertolongan secara mendadak. Dalam gambar tersebut terlihat bahwa siswa PMR sedang mengobati siswa lain yang mengalami luka akibat terjatuh. 


\subsubsection{Bakti Sosial}

Bakti sosial adalah kegiatan yang dilakukan untuk melatih kepedulian sosial siswa anggota PMR pada orang lain yang membutuhkan. Adapun bakti sosial yang pernah dilakukan adalah penyuluhan kebersihan dan kesehatan pada Panti Asuhan Harapan Putra Asrori Malang.

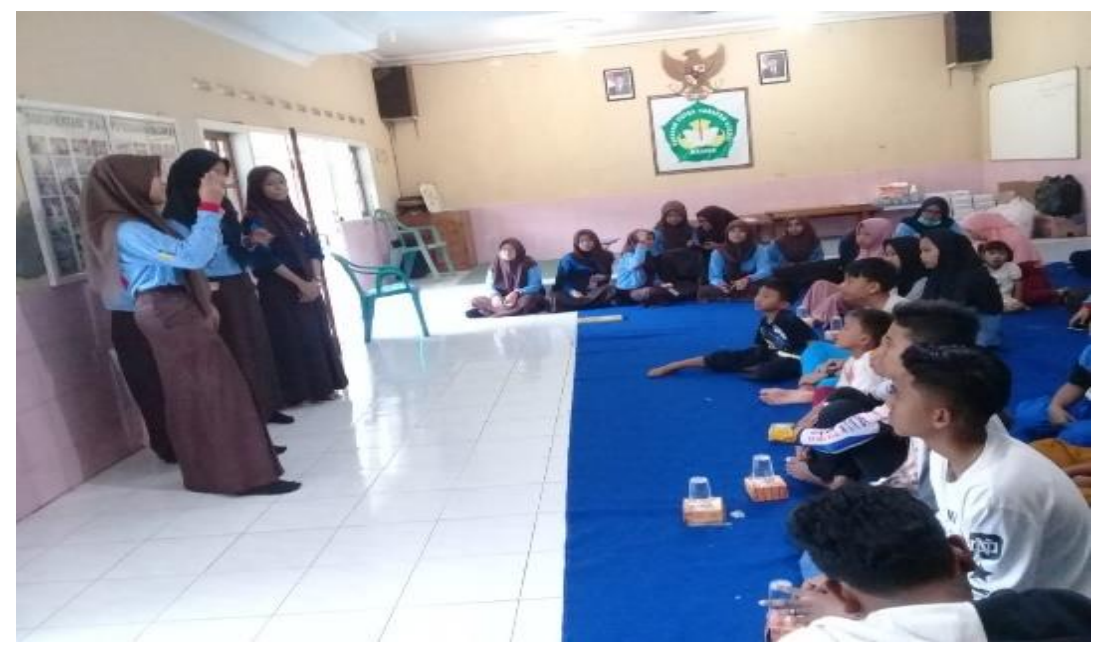

\section{Gambar 5. Siswa PMR melakukan bakti sosial di Panti Asuhan Putra Harapan Asrori Sumber: Dokumentasi Pribadi (2019)}

Gambar 5 menunjukkan bahwa siswa PMR sedang melakukan bakti sosial di Panti Asuhan Putra Harapan Asrori. Adapun kegiatan yang dilakukan adalah (1) penyuluhan tentang cuci tangan yang benar, (2) penjelasan tata cara penanganan luka, dan (3) tata cara agar hidup sehat. Selain melakukan penyuluhan kebersihan dan kesehatan, siswa PMR juga memberikan paket kebersihan untuk masing-masing penghuni panti dan paket obat-obatan serta paket kebersihan. Pemberian paket kebersihan dan obat-obatan bertujuan untuk menunjang panti asuhan agar senantiasa hidup bersih dan sehat.

\subsubsection{Sosialisasi ke Ekstrakurikuler Lain}

Pembina ekstrakurikuler PMR menginginkan agar ilmu yang dipelajari siswa PMR selama latihan rutin juga dapat disosialisasikan kepada teman-temannya di sekolah. Untuk memfasilitasi keinginan ini, pihak sekolah memberikan izin kepada siswa melakukan sosialisasi. Sosialisasi dilakukan pada siswa-siswa ekstrakurikuler lain yaitu voli, futsal, paskibra, dan pencak silat. Dalam Gambar 6 di bawah ini tampak siswa PMR sedang melakukan sosialisasi ke ekstrakurikuler lain. 


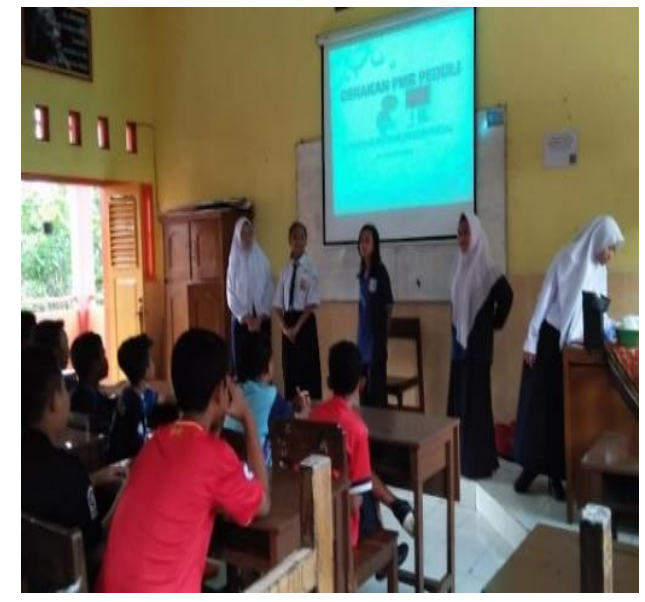

(a)

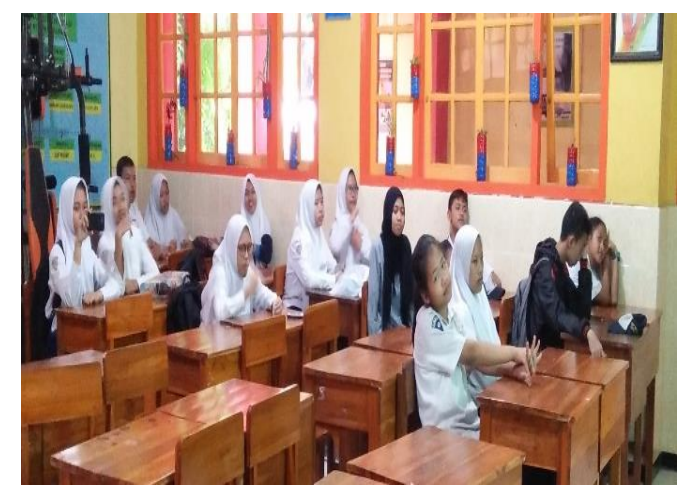

(c)

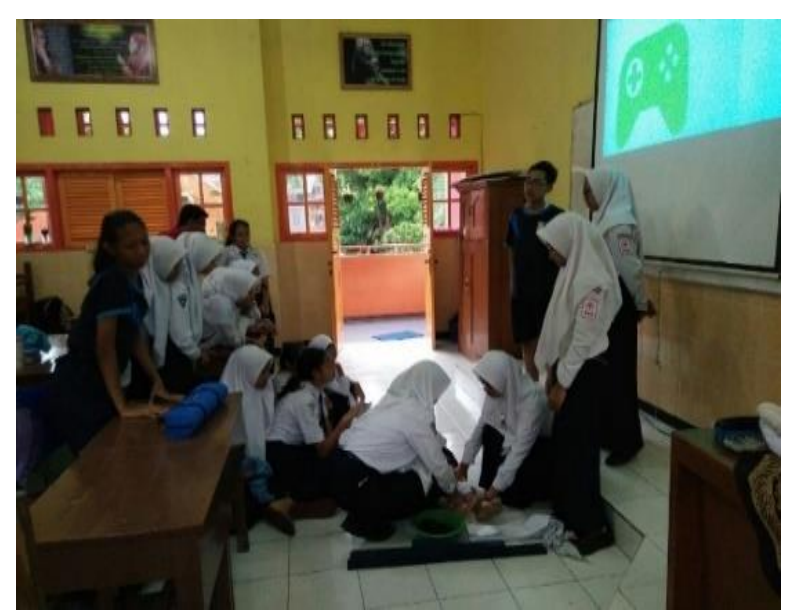

(b)

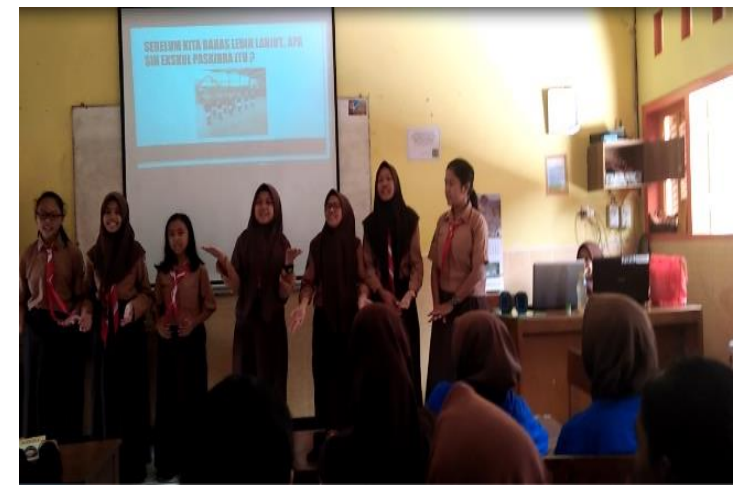

(d)

Gambar 6. (A) Sosialisasi Ke Ekstrakurikuler Futsal, (B) Sosialisasi Ke Ekstrakurikuler Voli, (C) Sosialisasi Ke Ekstrakurikuler Pencak Silat, Bagian (4) Sosialisasi Ke Ekstrakurikuler

\section{Paskibra}

\section{Sumber: Dokumentasi Sekolah (2018)}

Siswa PMR senang mengikuti kegiatan ekstrakurikuler PMR. Berdasarkan hasil wawancara dengan siswa PMR, siswa mengatakan bahwa dirinya gembira mengikuti kegiatan ekstrakurikuler PMR karena dapat mempelajari ilmu kesehatan. Salah satu siswa mengaku bahwa dirinya suka mempelajari ilmu kesehatan karena dapat menjaga tubuh agar tetap sehat dan dapat menyalurkan ilmu yang ia dapat ke orang lain. Selain itu, siswa PMR lain juga mengaku bahwa mengikuti ekstrakurikuler seru dan tidak membosankan karena diselingi praktik.

Pembina ekstrakukuler mengaku bahwa tujuan adanya kegiatan ekstrakurikuler PMR di SMPN 8 Malang adalah agar siswa tidak hanya mendapatkan pengetahuan tentang ilmu kepalangmerahan, namun juga dapat mempraktikkannya kepada teman, keluarga, dan masyarakat, sehingga hal ini dapat menanamkan sikap kepedulian sosial pada diri siswa PMR. 


\subsection{Pembahasan}

Bentuk kegiatan ekstrakurikuler PMR di SMPN 8 Malang adalah latihan rutin, siaga kesehatan, bakti sosial, dan sosialisasi ke ekstrakurikuler lain. Kegiatan tersebut bertujuan agar siswa mendapatkan pengetahuan tentang kesehatan dan dapat mempraktikkannya dalam kehidupan sehari-hari baik kepada diri sendiri, keluarga, teman, dan masyarakat sekitar. Latihan rutin ekstrakurikuler PMR berupa pemberian materi tentang ilmu kepalangmerahan dan ilmu yang didapat tersebut dapat dipraktikkan siswa saat sedang siaga kesehatan, karena pada saat siaga kesehatan siswa terjun langsung ke lapangan untuk memberikan pertolongan pertama kepada orang yang membutuhkan bantuan kesehatan (Makhfudzo, 2014).

Bakti sosial dan sosialisasi ke ekstrakurikuler lain juga merupakan bentuk dari kegiatan ekstrakurikuler PMR SMPN 8 Malang bersifat sosial yang bertujuan agar siswa dapat membagikan ilmu kesehatan yang diperolehnya terhadap teman dan masyarakat di sekitarnya. Kegiatan tersebut bertujuan untuk meningkatkan rasa kepedulian sosial siswa terhadap lingkungan sekitarnya. Hal ini didukung oleh pendapat Tabi'in (2017) yang mengatakan bahwa kepedulian sosial anak dapat dibangun dengan melibatkan anak dalam kegiatan sosial. Partisipasi yang dilakukakan siswa berupa terjun langsung ke lapangan melakukan kegiatan sosial dapat membuat siswa menjadi lebih peduli terhadap lingkungan sekitarnya.

Kegiatan yang dilaksanakan dalam ekstrakurikuler PMR berpedoman pada Tri Bakti PMR. Tri Bakti PMR berbunyi (1) meningkatkan keterampilan hidup sehat, (2) berbakti dan berkarya di masyarakat, dan (3) mempererat persahabatan nasional dan internasioal. Terselenggaranya kegiatan latihan rutin, siaga kesehatan, bakti sosial, dan sosialisasi ke ekstrakurikuler merupakan bentuk upaya terealisasinya kandungan Tri Bakti PMR dalam kehidupan siswa yang mengikuti ekstrakurikuler PMR.

\section{Simpulan}

Bentuk kegiatan ekstrakurikuler PMR di SMPN 8 Malang antara lain; latihan rutin, siaga kesehatan, bakti sosial, dan sosialisasi ke ekstrakurikuler lain. Kegiatan tersebut melatih siswa agar memiliki kepedulian sosial yang tinggi di lingkungan sekolah. Melalui kegiatan tersebut, diharapkan siswa dapat mempraktikkan ilmu yang didapatnya tersebut dalam bentuk melakukan tindakan kepedulian sosial.

\section{Daftar Rujukan}

Fathurrohman, P., Suryana, A. A., \& Fatriany, F. (2013). Pengembangan pendidikan karakter. Refika Aditama.

Isro'diyah, D., \& Warsono. (2017). Ekstrakurikuler Palang Merah Remaja dalam menumbuhkan kepedulian sosial siswa di SMP Negeri 2 Jombang. Kajian Moral Dan Kewarganegaraan, 5(2), 287-301. https://jurnalmahasiswa.unesa.ac.id/index.php/jurnal-pendidikankewarganegaraa/article/view/19765/18078

Makhfudzo, I. (2014). Pelaksanaan kegiatan ekstrakurikuler Palang Merah Remaja (PMR) dalam menumbuhkan kepedulian sosial siswa SMA Negeri 1 Malang. Jurnal Pendidikan Kewarganegaraan, $1(1)$

Prahesty, R. E., \& Suwanda, I. M. (2016). Peran ekstrakurikuler Palang Merah Remaja dalam membentuk sikap tolong menolong siswa di SMPN 5 Sidoarjo. Kajian Moral Dan Kewarganegaraan, 1(4), 201-215. https://core.ac.uk/download/pdf/230709929.pdf

Prasetyo, Y. (2010). Pengembangan ekstrakurikuler panahan di sekolah sebagai wahana membentuk karakter siswa. Jurnal Pendidikan Jasmai Indonesia, 7(2), 64-68. https://doi.org/10.21831/jpji.v7i2.421 
Jurnal Integrasi dan Harmoni Inovatif Ilmu-Ilmu Sosial (JIHI3S), 1(1), 2021, 14-22

Tabi'in, A. (2017). Menumbuhkan sikap peduli pada anak melalui interaksi kegiatan sosial. IJTIMAIYAH: Journal of Social Science and Teaching, 39-59. https://journal.iainkudus.ac.id/index.php/Ijtimaia/article/view/3100/2309

Yusuf, L. N., Sugandhi, S., \& Nani, M. (2012). Perkembangan peserta didik. PT Raja Grafindo Persada. 